\title{
RADIOCARBON CHRONOLOGY OF LATE GLACIAL AND HOLOCENE SEDIMENTATION AND WATER-LEVEL CHANGES IN THE AREA OF THE GOŚCIĄŻ LAKE BASIN
}

\author{
ANNA PAZDUR, ${ }^{1}$ M. F. PAZDUR, ${ }^{1}$ TOMASZ GOSLAR, ${ }^{1}$ BOGUMIE WICIK ${ }^{2}$ and \\ MAURICE ARNOLD
}

\begin{abstract}
We obtained ${ }^{14} \mathrm{C}$ ages on samples of lake marl and other sediments from cores taken in Gościazz Lake and its environs. Comparison of ${ }^{14} \mathrm{C}$ dates of bulk samples of laminated sediment with varve chronology and available AMS dates of terrestrial macrofossils indicates a reservoir correction of $2000 \pm 120 \mathrm{yr}$ for the basal series of lake sediments. ${ }^{14} \mathrm{C}$ dates obtained on peat layers underlying the oldest lacustrine sediments in Gosciąz and other lakes consistently locate the beginning of organogenic sedimentation in this area at $c a .13 \mathrm{ka} \mathrm{BP}$. We distinguished three periods of lacustrine gyttja sedimentation in cores taken in Gościąż and adjacent lakes: $11.8-10.2 \mathrm{ka}, 8-7 \mathrm{ka}$ and 2.7-2.1 ka BP. From the ${ }^{14} \mathrm{C}$ dates of lithological boundaries in these cores, we reconstruct a pattern of lake-level changes during the last $12 \mathrm{ka}$, remarkably similar to Swedish lakes and generally agreeing with available records from European and American lakes. The behavior of Gosciaż Lake during the last 12 ka fairly well reflects global climate changes in the temperate zone during the Late Glacial and Holocene periods.
\end{abstract}

\section{INTRODUCTION}

Gościąz Lake, situated in the Płock Basin (Fig. 1), is the largest and the deepest in the system of the four "Na Jazach" lakes drained by the small Ruda Creek. The significance of this lake was recognized immediately after discovery of its laminated sediment in 1985 . Over $18 \mathrm{~m}$ of Gościąż Lake's basal sediments consist of carbonaceous-sulphuric gyttja with a large amount of iron and other elements, accumulated in a superaqueous environment dominated by reduction processes. The sediment reveals distinct lamination, consisting of $\mathrm{ca}$. 12,500 laminae couplets, extending back from the present to the Allerød interstadial. Goslar et al. (1993) used varve chronology and AMS dates on macrofossils from Gościąż Lake to determine the duration of the Younger Dryas.

\section{DESCRIPTION OF THE STUDY AREA}

The Plock Basin is located in a glaciated area near the maximum southern advance of the Vistulian ice sheet, among the $>60$ lakes of the Gostynin Lakeland. The region's mean annual temperature is $7.9^{\circ} \mathrm{C}$; January and July mean temperatures are $-1.6^{\circ} \mathrm{C}$ and $18.7^{\circ} \mathrm{C}$, respectively. Annual precipitation is $c a .520 \mathrm{~mm}$ and evaporation ca. $412 \mathrm{~mm}$; dominating winds are westerly (Sierżęga and Narwojsz 1988).

Quaternary sediments of the Plock Basin were formed mostly during the last glaciation. Glacial tills, kame and ooze sands occur in the eastern part of the Plock Basin; sands and gravels dominate in the vicinity of Gościąz Lake. Most of the Plock Basin is covered with glaciofluvial sands and gravels deposited at the decline of the Poznań phase and before the beginning of the Pomeranian phase of the Vistulian glaciation. The surface of glaciofluvial sediments is marked by numerous subglacial troughs and melt-out basins, some forming present-day lakes. The initial glacial relief of the region is hidden by dunes of Late Glacial age.

Underlying the Quaternary sediments are Pliocene clays with layers of silts, silty/clayey sands and Miocene sands, clays and silts with layers of brown coal up to $5 \mathrm{~m}$ thick. Siderite concretions and

\footnotetext{
${ }^{1}$ Radiocarbon Laboratory, Silesian Technical University, Krzywoustego 2, PL-44-100 Gliwice, Poland

${ }^{2}$ Faculty of Geography, Warsaw University, Krakowskie Przedmieście 30, PL-00-927 Warsaw, Poland

${ }^{3}$ Centre des Faibles Radioactivités, Laboratoire mixte CNRS-CEA, Domaine du CNRS, Avenue de la Terrasse,

F-91198 Gif sur Yvette Cedex, France
} 

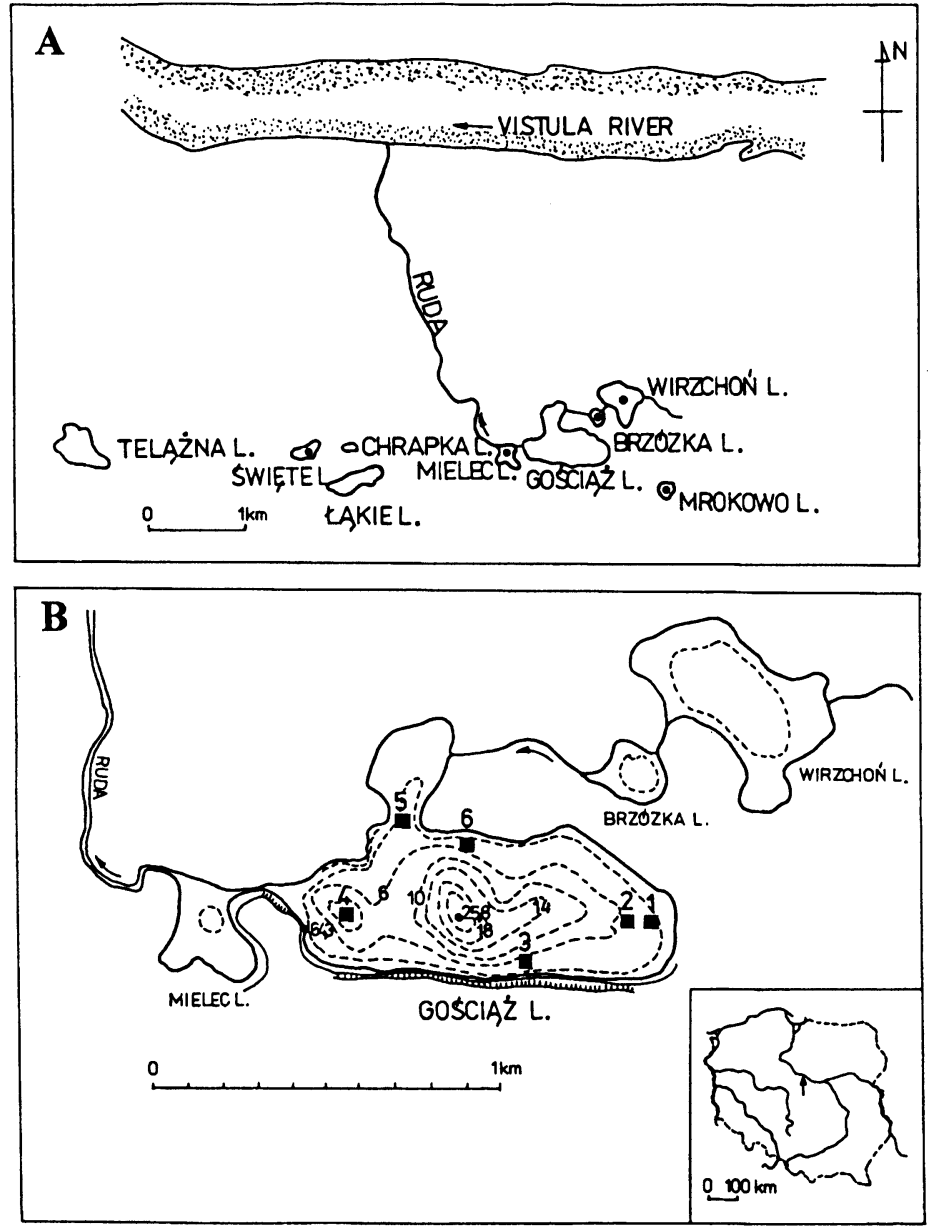

Fig. 1. Map of the study area. A. Environs of Gościąż Lake; • = cores from other lakes. B. Simplified bathymetric chart of the $\mathrm{Na}$ Jazach lake system. $\mathbf{a}=$ coring locations in Gosciąz Lake; numbers = profiles shown in Fig. 2. Note: cores of laminated sediment from the central depression at water depth $25.8 \mathrm{~m}$ are not explicitly shown.

pyrite can be found in the Pliocene clays. The varied surface of Tertiary sediments exhibits denivellations of up to $130 \mathrm{~m}$, caused by erosion, evorsion and glaciotectonic processes (Skompski 1971; Madeyska 1993).

Gościąż Lake forms an intermediate stage of a system of four lakes drained by Ruda Creek (Fig. 1). The input to the system is on the eastern side of Wirzchon Lake at the mouth of a small stream that drains several peaty and boggy depressions; output is from the western part of Mielec Lake. The four lakes form a cascade system dropping from Wirzchon Lake, $64.4 \mathrm{~m}$ asl. This lake, which captures most of the allochthonous material, is presently $c a .2 .6 \mathrm{~m}$ deep, and its basal sediments are 12.5 m thick.

The distinct chemical characteristics of groundwater in the drainage basin of the lake system indicate that Gościąż Lake is supplied by surface water from recent precipitation and by underground seepage from water-bearing Pleistocene sands and much deeper Pliocene/Miocene beds (Wicik and Więckowski 1991). The present surface area of Gościąż Lake is $0.45 \mathrm{~km}^{2}$. It has two distinct basal depressions: a central one with a maximum depth of $25.8 \mathrm{~m}$, in the form of an elliptical cone extending SE-NW for ca. $300 \mathrm{~m}$ (Więckowski 1993), and a western one of similar shape and dimension, slightly $>12 \mathrm{~m}$ deep. A third shallow depression in the eastern lake basin is not marked on the bathy- 
metric chart of the lake. The lacustrine sediments vary in thickness from $c a .7 \mathrm{~m}$ to $c a .18 \mathrm{~m}$ in the depressions. In both eastern and western depressions, the lacustrine sediments overlie a thin peaty layer showing pollen spectra typical for the Allerød period (Ralska-Jasiewiczowa, Wicik and Więckowski 1987). Close examination of other cores shows that lacustrine sediments were deposited directly on sands with fragments of lignite. In the core taken $c a .350 \mathrm{~m}$ east of the central depression, below a series of sandy sediments of Pleistocene age, a level of gravels directly overlies Pliocene silts.

\section{METHODS}

We collected samples for ${ }^{14} \mathrm{C}$ dating from core segments 5 or $10 \mathrm{~cm}$ thick. Cores of laminated sediment were analyzed at the Institute of Botany, Polish Academy of Sciences, Krakow, by T. Goslar; other cores were analyzed at the Institute of Geography, Warsaw University, by A. Pazdur and B. Wicik. Samples of laminated sediment were pretreated with $0.5 \mathrm{~N} \mathrm{HCl}$; evolved $\mathrm{CO}_{2}$ was trapped and, after purification, was used for ${ }^{14} \mathrm{C}$ activity measurements. Insoluble residue was washed until neutral reaction, dried and combusted in an oxygen stream. ${ }^{14} \mathrm{C}$ activity was measured using proportional counters filled with pure $\mathrm{CO}_{2}$. We collected small aliquots of $\mathrm{CO}_{2}$ for $\delta^{13} \mathrm{C}$ determinations just before filling the proportional counters. All $\delta^{13} \mathrm{C}$ analyses were made on an MI1305 mass spectrometer at the Institute of Physics, Maria Curie Skłodowska University, Lublin.

Samples from other cores were treated with $0.5 \mathrm{~N} \mathrm{HCl}$ to remove carbonates and, after washing and drying, were combusted to $\mathrm{CO}_{2}$ and counted. We used only the organic fraction for ${ }^{14} \mathrm{C}$ determinations on most samples. Both old and new oxalic acid standards were used as modern reference samples. Ages were calculated according to the recommendations of Stuiver and Polach (1977). Plant fragments for accelerator mass spectrometry (AMS) dating were separated from 10-yr segments of core by $\mathbf{Z}$. Tomczynska-Moskwa, and terrestrial macrofossils were identified and selected by $\mathrm{M}$. Ralska-Jasiewiczowa at the Institute of Botany, Krakow. Because of the very low mass obtained, individual samples separated from adjacent 10-yr segments of core were combined at the Centre des Faibles Radioactivités, Gif sur Yvette, to obtain enough carbon for AMS dating (Arnold et al. 1987).

\section{RADIOCARBON CHRONOLOGY OF GOŚCIĄŻ LAKE SEDIMENTS}

Beginning with the first coring in 1985, which yielded the first long laminated sequence (Pazdur et al. 1987a,b; Ralska-Jasiewiczowa, Wicik and Więckowski 1987), four other cores of laminated sediment were collected from the central depression at water depth $25.8 \mathrm{~m}$ ( $c f$. Fig. 1B). These cores were used to establish a detailed varve chronology (Goslar 1993) as well as for isotopic and paleoecologic studies (Różański et al. 1992; Goslar et al. 1992). Bulk samples of laminated sediment from cores $\mathrm{G} 1 / 85, \mathrm{G} 1 / 87, \mathrm{G} 2 / 87$ and $\mathrm{G} 1 / 90$ were used for ${ }^{14} \mathrm{C}$ age determinations on both carbonate and total organic matter fractions. Preliminary results were reported elsewhere (Pazdur et al. 1987a,b; Goslar et al. 1989) and were also used for tentative reconstruction of lake-level changes (Pazdur and Starkel 1989). Table 1 lists ${ }^{14} \mathrm{C}$ age determinations of all laminated sediment samples. Pazdur et al. (ms. in preparation) will discuss in detail the significance of isotopic data obtained from long cores of laminated sediment.

The size of the reservoir effect estimated by comparing varve chronology and ${ }^{14} \mathrm{C}$ dates obtained on bulk samples of laminated sediment varies with time and ranges from 900 to $3100 \mathrm{yr} .{ }^{14} \mathrm{C}$ content of dissolved inorganic carbon (DIC) of groundwater supplying the lake ranges from 63.4 to $70.0 \mathrm{pMC}$ and in lake water equals $82.5 \pm 1.7 \mathrm{pMC}$. Table 2 lists the results of AMS-dated terrestrial macrofossils separated from well-defined levels of laminated-sediment cores G1/97 and G2/97, obtained at the Gif 
TABLE $1 .{ }^{14} \mathrm{C}$ Dates Obtained on Samples of Laminated Sediment From Cores Taken in the Central Depression of Gościąż Lake, Water Depth $25.8 \mathrm{~m}$

\begin{tabular}{|c|c|c|c|}
\hline $\begin{array}{l}\text { Lab no. } \\
\text { (Gd-) }\end{array}$ & Sample, depth & ${ }^{14} \mathrm{C}$ age (BP) & $\delta^{13} \mathrm{C}(\%)$ \\
\hline 2583 & $\mathrm{G} 1 / 85 / 1.5-1.6 \mathrm{~m} / \mathrm{C}^{*}$ & $2100 \pm 90$ & -0.99 \\
\hline 4066 & $\mathrm{G} 1 / 85 / 1.5-1.6 \mathrm{~m} / \mathrm{O} \dagger$ & $1730 \pm 100$ & -30.24 \\
\hline 3230 & $\mathrm{G} 1 / 85 / 2.65-2.75 \mathrm{~m} / \mathrm{C}$ & $2200 \pm 40$ & 1.20 \\
\hline 2649 & $\mathrm{G} 1 / 85 / 2.65-2.75 \mathrm{~m} / \mathrm{O}$ & $2340 \pm 80$ & -29.30 \\
\hline 5008 & $\mathrm{G} 1 / 85 / 3.05-3.15 \mathrm{~m} / \mathrm{C}$ & $3660 \pm 50$ & 0.00 \\
\hline 2571 & $\mathrm{G} 1 / 85 / 3.05-3.15 \mathrm{~m} / \mathrm{O}$ & $2730 \pm 120$ & -30.36 \\
\hline 5082 & $\mathrm{G} 1 / 85 / 3.9-4.0 \mathrm{~m} / \mathrm{C}$ & $3880 \pm 70$ & 1.26 \\
\hline 2620 & $\mathrm{G} 1 / 85 / 3.9-4.0 \mathrm{~m} / \mathrm{O}$ & $3050 \pm 80$ & -28.55 \\
\hline 2618 & $\mathrm{G} 1 / 85 / 4.9-5.0 \mathrm{~m} / \mathrm{C}$ & $4680 \pm 120$ & 1.61 \\
\hline 2621 & $\mathrm{G} 1 / 85 / 4.9-5.0 \mathrm{~m} / \mathrm{O}$ & $3800 \pm 90$ & -30.17 \\
\hline 3277 & $\mathrm{G} 1 / 85 / 6.1-6.2 \mathrm{~m} / \mathrm{C}$ & $5350 \pm 50$ & -1.20 \\
\hline 2527 & $\mathrm{G} 1 / 85 / 6.1-6.2 \mathrm{~m} / \mathrm{O}$ & $4230 \pm 120$ & -31.52 \\
\hline 5086 & $\mathrm{G} 1 / 85 / 6.9-7.0 \mathrm{~m} / \mathrm{C}$ & $5690 \pm 80$ & 0.49 \\
\hline 2623 & $\mathrm{G} 1 / 85 / 6.9-7.0 \mathrm{~m} / \mathrm{O}$ & $5040 \pm 110$ & -30.67 \\
\hline 5094 & $\mathrm{G} 1 / 85 / 7.9-8.0 \mathrm{~m} / \mathrm{C}$ & $6280 \pm 80$ & 0.35 \\
\hline 2626 & $\mathrm{G} 1 / 85 / 7.9-8.0 \mathrm{~m} / \mathrm{O}$ & $5530 \pm 100$ & -30.63 \\
\hline 5088 & $\mathrm{G} 1 / 85 / 8.9-9.0 \mathrm{~m} / \mathrm{C}$ & $7390 \pm 190$ & -0.04 \\
\hline 4100 & $\mathrm{G} 1 / 85 / 8.9-9.0 \mathrm{~m} / \mathrm{O}$ & $6320 \pm 120$ & -31.37 \\
\hline 1992 & $\mathrm{G} 1 / 85 / 9.60-9.65 \mathrm{~m} / \mathrm{C}$ & $7930 \pm 70$ & -1.05 \\
\hline 2564 & $\mathrm{G} 1 / 85 / 9.60-9.65 \mathrm{~m} / \mathrm{O}$ & $6840 \pm 390$ & -32.00 \\
\hline 5091 & $\mathrm{G} 1 / 85 / 10.0-10.1 \mathrm{~m} / \mathrm{C}$ & $8190 \pm 100$ & -0.49 \\
\hline 5372 & $\mathrm{G} 1 / 85 / 10.0-10.1 \mathrm{~m} / \mathrm{O}$ & $7630 \pm 120$ & -31.23 \\
\hline 5095 & $\mathrm{G} 1 / 85 / 10.45-10.55 \mathrm{~m} / \mathrm{C}$ & $8420 \pm 90$ & -2.16 \\
\hline 4105 & $\mathrm{G} 1 / 85 / 10.45-10.55 \mathrm{~m} / \mathrm{O}$ & $7880 \pm 150$ & -31.59 \\
\hline 5096 & $\mathrm{G} 1 / 85 / 11.0-11.1 \mathrm{~m} / \mathrm{C}$ & $8800 \pm 70$ & -1.80 \\
\hline 3231 & $\mathrm{G} 1 / 85 / 11.45-11.50 \mathrm{~m} / \mathrm{C}$ & $9160 \pm 50$ & -4.54 \\
\hline 2476 & $\mathrm{G} 1 / 85 / 11.45-11.50 \mathrm{~m} / \mathrm{O}$ & $8960 \pm 120$ & -32.00 \\
\hline 5098 & $\mathrm{G} 1 / 85 / 12.0-12.1 \mathrm{~m} / \mathrm{C}$ & $10,230 \pm 90$ & -6.05 \\
\hline 2627 & $\mathrm{G} 1 / 85 / 12.5-12.6 \mathrm{~m} / \mathrm{C}$ & $10,710 \pm 150$ & -6.38 \\
\hline 4103 & $\mathrm{G} 1 / 85 / 12.5-12.6 \mathrm{~m} / \mathrm{O}$ & $10,240 \pm 250$ & -34.08 \\
\hline 5099 & $\mathrm{G} 1 / 85 / 13.0-13.1 \mathrm{~m} / \mathrm{C}$ & $10,830 \pm 80$ & -6.58 \\
\hline 4104 & $\mathrm{G} 1 / 85 / 13.0-13.1 \mathrm{~m} / \mathrm{O}$ & $10,790 \pm 220$ & -34.34 \\
\hline 3225 & $\mathrm{G} 1 / 85 / 13.5-13.55 \mathrm{~m} / \mathrm{C}$ & $10,640 \pm 60$ & -8.29 \\
\hline 2464 & $\mathrm{G} 1 / 85 / 13.5-13.55 \mathrm{~m} / \mathrm{O}$ & $10,640 \pm 100$ & -35.44 \\
\hline 3223 & $\mathrm{G} 1 / 85 / 14.45-14.50 \mathrm{~m} / \mathrm{C}$ & $12,100 \pm 90$ & -6.96 \\
\hline 4067 & $\mathrm{G} 1 / 85 / 14.45-14.50 \mathrm{~m} / \mathrm{O}$ & $11,270 \pm 350$ & -34.23 \\
\hline 4007 & $\mathrm{G} 1 / 85 / 15.0-15.05 \mathrm{~m} / \mathrm{C}$ & $12,570 \pm 130$ & -7.82 \\
\hline 4013 & $\mathrm{G} 1 / 85 / 15.0-15.05 \mathrm{~m} / \mathrm{O}$ & $11,980 \pm 430$ & -33.00 \\
\hline 2584 & $\mathrm{G} 1 / 85 / 15.4-15.5 \mathrm{~m} / \mathrm{O}$ & $12,650 \pm 140$ & -33.19 \\
\hline 5048 & $\mathrm{G} 1 / 85 / 15.40-15.50 \mathrm{~m} / \mathrm{C}$ & $13,480 \pm 120$ & -8.02 \\
\hline 5444 & $\mathrm{G} 1 / 87 / 4.01-4.10 \mathrm{~m} / \mathrm{C}$ & $3850 \pm 70$ & 0.75 \\
\hline 5442 & $\mathrm{G} 1 / 87 / 4.31-4.40 \mathrm{~m} / \mathrm{C}$ & $3720 \pm 70$ & 1.38 \\
\hline 5441 & $\mathrm{G} 1 / 87 / 5.02-5.11 \mathrm{~m} / \mathrm{C}$ & $3610 \pm 60$ & 1.85 \\
\hline 5377 & $\mathrm{G} 1 / 87 / 6.15-6.25 \mathrm{~m} / \mathrm{C}$ & $4520 \pm 50$ & 0.48 \\
\hline 5376 & $\mathrm{G} 1 / 87 / 7.00-7.10 \mathrm{~m} / \mathrm{C}$ & $4540 \pm 70$ & 0.56 \\
\hline 5375 & $\mathrm{G} 1 / 87 / 7.90-8.00 \mathrm{~m} / \mathrm{C}$ & $5430 \pm 60$ & 0.64 \\
\hline 5374 & $\mathrm{G} 1 / 87 / 9.02-9.10 \mathrm{~m} / \mathrm{C}$ & $6130 \pm 60$ & 0.02 \\
\hline
\end{tabular}


TABLE 1. (Continued)

\begin{tabular}{llcc}
\hline $\begin{array}{l}\text { Lab no. } \\
\text { (Gd-) }\end{array}$ & Sample, depth & ${ }^{14} \mathrm{C}$ age (BP) & $\delta^{13} \mathrm{C}(\%)$ \\
\hline 2888 & G1/87/9.42-9.52m/C & $5270 \pm 90$ & 0.04 \\
2889 & G1/87/10.66-10.72m/C & $7350 \pm 120$ & -0.78 \\
5373 & G1/87/10.93-11.0m/C & $7620 \pm 60$ & -0.92 \\
5372 & G1/87/11.33-11.40m/C & $7800 \pm 70$ & -1.35 \\
5242 & G1/87/16.92-16.98m/C & $13,240 \pm 120$ & -10.20 \\
2771 & G1/87/16.92-16.98m/O & $13,780 \pm 200$ & -34.00 \\
6371 & G2/87/16.02-16.10m/C & $11,980 \pm 170$ & -8.37 \\
5853 & G2/87/16.10-16.20m/C & $11,700 \pm 120$ & -4.12 \\
4676 & G2/87/16.10-16.20m/O & $10,470 \pm 180$ & $-30.00 \ddagger$ \\
6355 & G1/90/14.89-14.92/O1 & $11,970 \pm 130$ & -29.46 \\
4669 & G1/90/14.89-14.92/O2 & $12,350 \pm 260$ & -25.00 \\
\hline "C = carbonate fraction & & \\
†O organic fraction & & \\
†Assumed value &
\end{tabular}

sur Yvette AMS facility. Różański et al. (1992) and Goslar et al. (1992) discussed the significance of these results for extending the calibration of the ${ }^{14} \mathrm{C}$ time scale to the Late Glacial period.

For this study, we used the data listed in Tables 1 and 2 to evaluate the magnitude of the reservoir correction ("hard-water effect"). One may compare two independent time scales with the ${ }^{14} \mathrm{C}$ dates of bulk samples of lake marl to derive the reservoir correction: the varve chronology elaborated by Goslar (1993), and the AMS dates listed in Table 2. The first approach yields a reservoir correction value of $2070 \pm 120 \mathrm{yr}$, whereas the second approach yields a value of $1900 \pm 120 \mathrm{yr}$. In both cases, we compared ten pairs of dates covering the Late Glacial segment of laminated sediment. From this comparison, we conclude that the reservoir correction for the basal sediments of Gościąż Lake is $2000 \pm 120$ yr. The observed scatter of individual differences in both cases is similar, with a standard deviation of $\mathrm{s}_{1}=360 \mathrm{yr}$.

TABLE 2. AMS Dates of Terrestrial Macrofossils from Core G2/87, Gościąż Lake

\begin{tabular}{rrlr}
\hline Sample & Varves & Sample material & ${ }^{14}$ C age (BP) \\
\hline G201M & $354-362$ & Pinus seedling, wood & $10,030 \pm 250$ \\
G202M & $363-371$ & Pinus needle, Betula nutlet & $10,450 \pm 140$ \\
G223M & & & \\
+G224M & & & \\
+G225M & $637-666$ & Betula nutlet, seed, scales & $9600 \pm 280$ \\
G233M & $754-763$ & Bark & $9950 \pm 150$ \\
G236M & & & \\
+G237M & $794-813$ & Betula nutlets, scales & $9870 \pm 150$ \\
G238M & $824-833$ & Betula nutlets, scales & $9870 \pm 330$ \\
G244M & & & \\
+G245M & & & $10,040 \pm 240$ \\
+G245AM & $886-910$ & Bud scales \\
G252M & & & $10,360 \pm 160$ \\
+G255M & $973-1020$ & Pinus seedlings, Betula nutlets & $9750 \pm 210$ \\
G264M & $1121-1130$ & Plant detritus & $10,050 \pm 120$ \\
G268M & $1171-1180$ & Pinus needles & \\
\hline & & &
\end{tabular}


As a supplement to this study, we sampled a series of 12 cores along two lines in a W-E direction, to determine the thickness and stratigraphy of the lake sediments; we ${ }^{14} \mathrm{C}$-dated six cores. Figure $1 \mathrm{~B}$ shows core locations. Figure 2 shows the profiles of the cores and Table 3 lists the results.
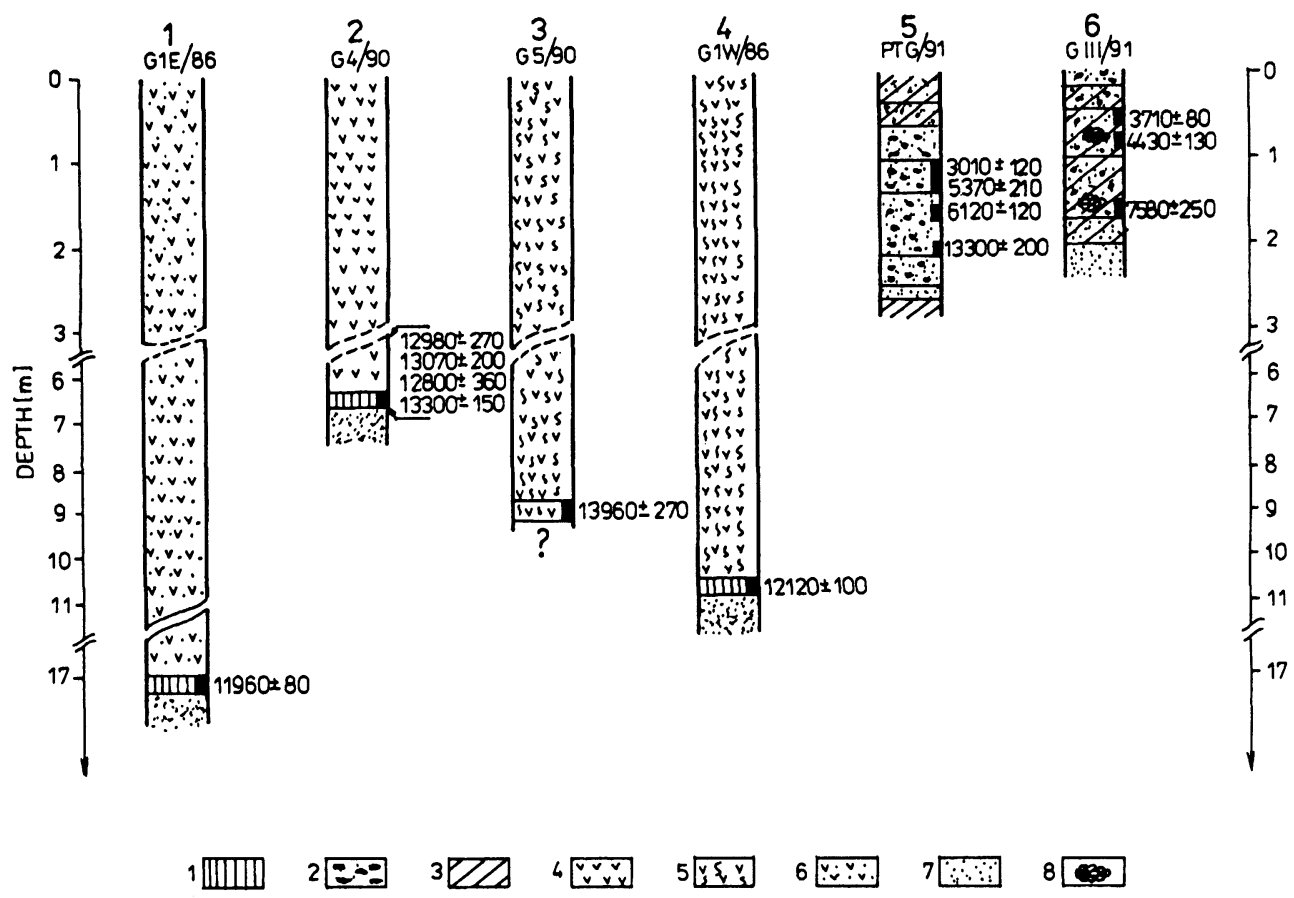

Fig. 2. Lithological profiles of sediment cores from Gosciąż Lake. Key: 1. peat; 2. macroscopic plant remains (bark, twigs, charcoal); 3. fine detrital gyttja; 4. algal gyttja; 5. sulphuric-calcareous gyttja; 6. calcareous gyttja; 7. sand; 8 . cone of Picea spp.

These results enable reliable and relatively precise dating of the beginning of organogenic sedimentation in the Gościąż Lake basin. The date of 13,300 $\pm 150 \mathrm{BP}$ obtained on the deepest segment of the basal layer of peat underlying the lacustrine series in profile G4/90 (Fig. 2) determines the beginning of organic sedimentation in the eastern part of the lake. Taking into account the mean value of two dates obtained on the middle peat layer (6.6-6.7 m depth), $13,010 \pm 170 \mathrm{BP}$, we obtain for the basal peat layer a series of three dates in good stratigraphic order. Because of relatively large dating errors, it seems reasonable to attribute to this peat layer the mean value of the whole set of four dates, $13,150 \pm 110 \mathrm{BP}$. This result coincides well with the date, 13,300 $\pm 200 \mathrm{BP}$, which determines the beginning of organic sedimentation in the profile PTG/91 (Core 5 in Fig. 1, taken at the boundary between Gościąż Lake and Tobyłka Bay), obtained on coarse-detrital gyttja.

Almost identical early dates were obtained on thin peat layers underlying lacustrine sediments in cores $\mathrm{G} 3 / 92$ and $\mathrm{G} 20 / 92(13,020 \pm 160 \mathrm{BP}$ and $13,240 \pm 150 \mathrm{BP}$, respectively), taken in peaty depressions of Ruda Creek valley at the eastern part of the study area (sampling points 11 and 13, Fig. 3). Similar dates were obtained on layers of peat and peaty detritus from basal sediment of Mielec and Wirzchoń Lakes (cf. Figs. 1 and 6 and Table 5). 
TABLE $3 .{ }^{14} \mathrm{C}$ dates of Cores Taken From Gościąż Lake

\begin{tabular}{cllc}
\hline $\begin{array}{c}\text { Lab no. } \\
\text { (Gd-) }\end{array}$ & Sample, depth & Sample material & ${ }^{14} \mathrm{C}$ age (BP) \\
\hline 3305 & G1E/86/17m & Peaty gyttja & $11,960 \pm 80$ \\
4683 & G4/90/6.55-6.60m & Peat & $12,980 \pm 270$ \\
6386 & G4/90/6.6-6.65m & Peat & $13,070 \pm 200$ \\
4691 & G4/90/6.6-6.7m & Peat & $12,800 \pm 360$ \\
5857 & G4/90/6.71-6.78m & Peat & $13,300 \pm 150$ \\
4688 & G5/90/9.04m & Calcareous gyttja & $13,960 \pm 270$ \\
4733 & GIII/91/0.45-0.60m & Detrital gyttja & $3710 \pm 80$ \\
4732 & GIII/91/0.70-0.90m & Detrital gyttja & $4430 \pm 130$ \\
4731 & GIII/91/1.50-1.70m & Detrital gyttja & $7580 \pm 250$ \\
4788 & PTG/91/1.00-1.34m & Charcoal & $3010 \pm 120$ \\
4790 & PTG/91/1.46-1.64m & Charcoal & $5370 \pm 210$ \\
4789 & PTG/91/1.94-2.12m & Wood and charcoal & $6120 \pm 120$ \\
4791 & PTG/91/2.67-2.69m & Coarse detrital gyttja & $13,300 \pm 200$ \\
5049 & G1W/86/11m & Peaty detrital gyttja & $12,120 \pm 110$ \\
\hline
\end{tabular}

\section{CHRONOLOGY OF SEDIMENTATION IN THE AREA OF GOŚCIĄŻ LAKE}

Lithofacially differentiated sediments from the area of the lake contain important information about the development of the lake system and changes of its hydrological regime, including changing water levels during the last $13 \mathrm{ka} \mathrm{BP}$. We conducted field work on these sediments for three seasons: in 1989, we sampled eight cores (Fig. 3); in 1992, we collected a second series of long cores reaching depths of $c a .8 \mathrm{~m}$ (Fig. 3); and we took 15 short cores along the southeast shore to determine the structure of subfossil lake terraces. From this series of corings, four samples were available for dating (LT-E1/92, LT-G3/92, LT-E5/92 and LT-J3/92 (Fig. 3); in 1993, we took two cores at the north shore of the lake (21 and 22 in Fig. 3). Figures 4 and 5 show detailed stratigraphy of some of these cores; Table 4 lists the ${ }^{14} \mathrm{C}$ results.

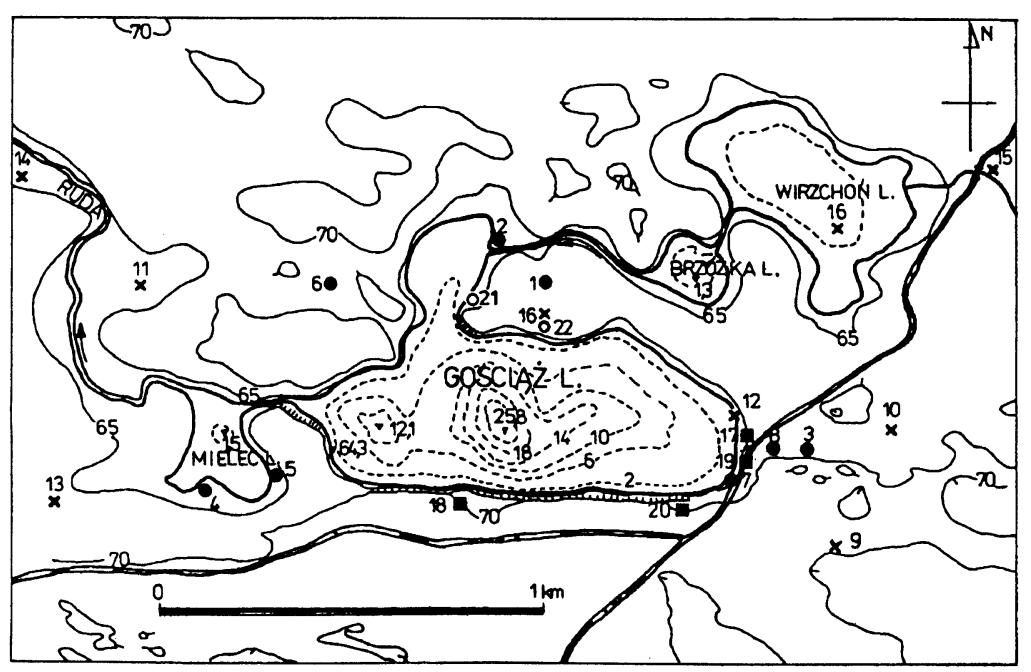

Fig. 3. Locations of cores and trenches around Gościąż Lake. $\bullet(1-8)=$ cores taken along the lakeshore in 1989; Fig. 4 shows lithological profiles. $\times(9-16)=$ cores taken in 1992; Fig. 5 shows lithological profiles (except core 16). $\square(17-20)$ $=$ trenches made in 1992 to determine the structure of lake terraces; profiles are not shown. $\circ(21-22)=$ cores taken in 1993. 


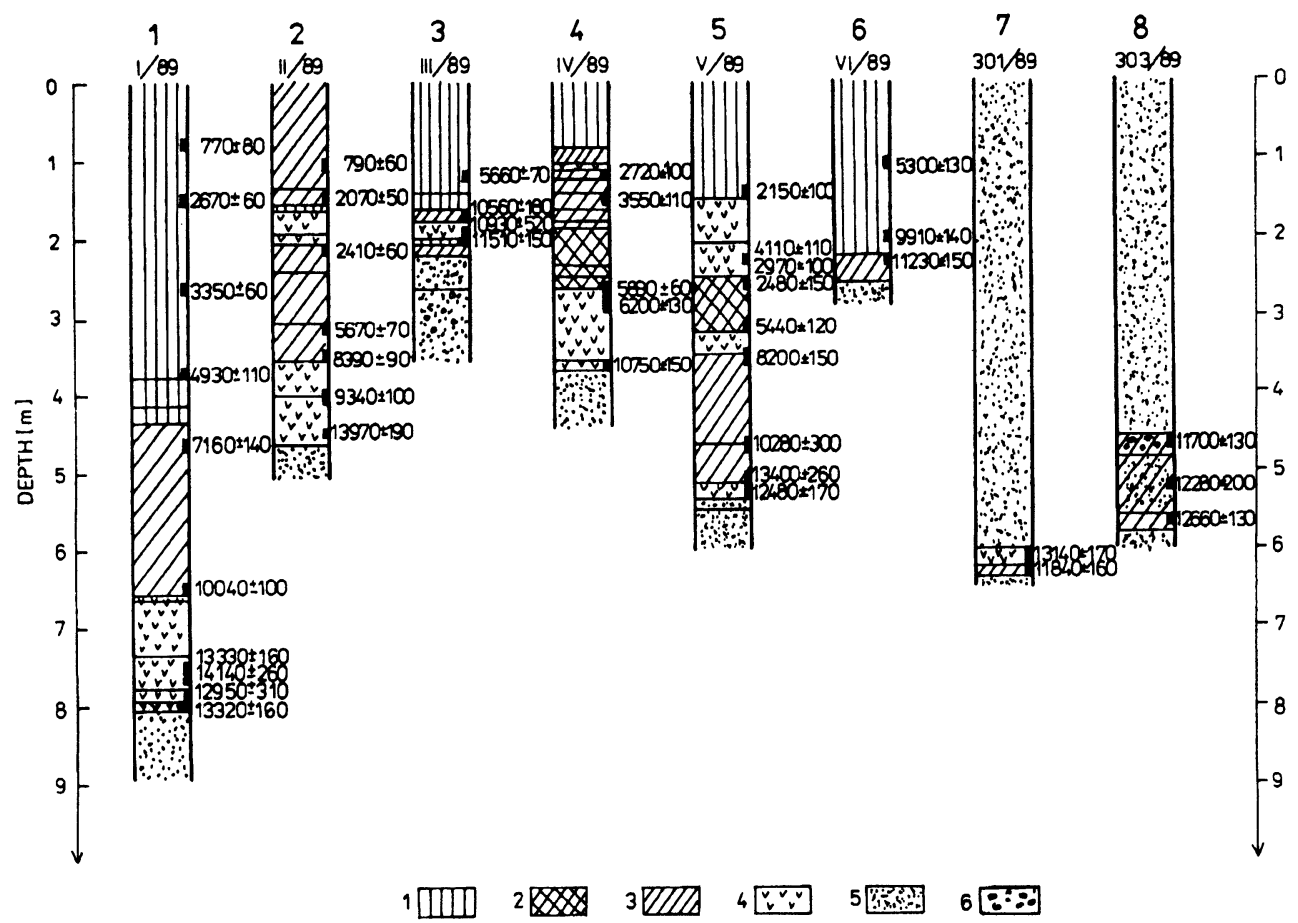

Fig. 4. Cores taken in 1989 around Gościąż and Mielec Lakes (• in Fig. 3): 1. peat; 2. decayed organic matter; 3. amorphous organic matter and humus sand; 4. lake marl (gyttja); 5. sand. Horizontal lines mark minor lithological boundaries.

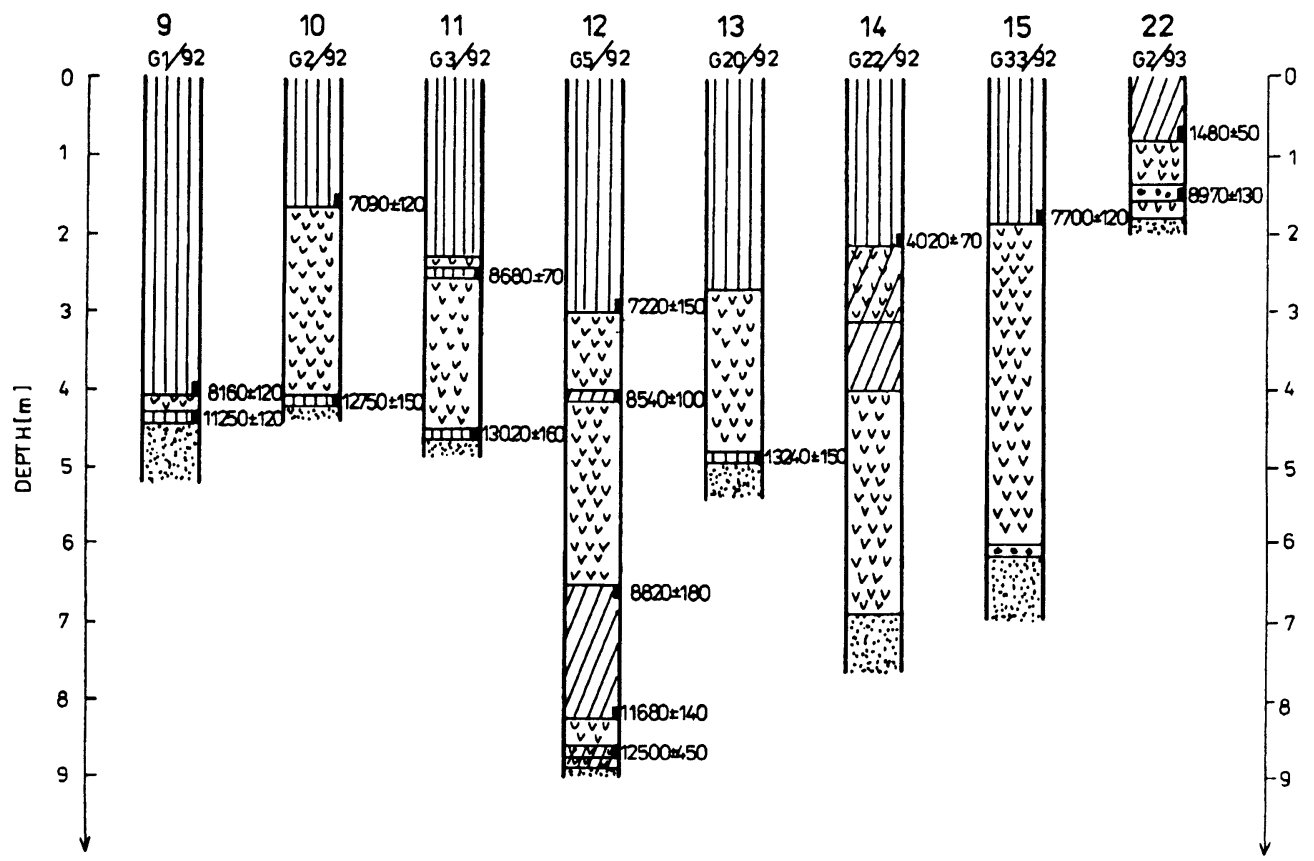

Fig. 5. Cores taken in 1992 and 1993; Fig. 3 shows locations. Key to lithological symbols is in Fig. 4. 
TABLE 4. ${ }^{14} \mathrm{C}$ Dates From Cores Taken in the Vicinity Of Gościąż Lake

\begin{tabular}{|c|c|c|c|}
\hline $\begin{array}{l}\text { Lab no. } \\
\text { (Gd-) }\end{array}$ & Sample, depth & Sample material & ${ }^{14} \mathrm{C}$ age (BP) \\
\hline 6171 & GTOI/89/0.7-0.8m & Peat & $770 \pm 80$ \\
\hline 5656 & GTOI/89/1.6-1.7m & Peat & $2670 \pm 60$ \\
\hline 5657 & GTOI/89/2.6-2.7m & Peat & $3350 \pm 60$ \\
\hline 6174 & GTOI/89/3.6-3.7m & Peat & $4930 \pm 110$ \\
\hline 6176 & GTOI/89/4.6-4.7m & Peat & $7160 \pm 140$ \\
\hline 5659 & GTOI/89/6.4-6.5m & Amorphous organic matter & $10,040 \pm 100$ \\
\hline 6219 & GTOI/89/7.6-7.7m & Calcareous gyttja & $13,330 \pm 160$ \\
\hline 6192 & GTOI/89/7.7-7.8m & Calcareous gyttja & $14,140 \pm 260$ \\
\hline 4549 & GTOI/89/7.8-7.93m & Calcareous gyttja & $12,950 \pm 310$ \\
\hline 4559 & GTOI/89/7.8-7.93m & Calcareous gyttja & $13,320 \pm 160$ \\
\hline 5678 & GTOII/89/1.00-1.15m & Amorphous organic matter & $790 \pm 60$ \\
\hline 5669 & GTOII/89/1.37-1.59m & Amorphous organic matter & $2070 \pm 50$ \\
\hline 5670 & GTOII/89/2.13-2.30m & Amorphous organic matter & $2410 \pm 60$ \\
\hline 5679 & GTOII/89/3.00-3.18m & Amorphous organic matter & $5670 \pm 70$ \\
\hline 5677 & GTOII/89/3.51-3.61m & Amorphous organic matter & $8390 \pm 90$ \\
\hline 5676 & GTOII/89/3.90-4.12m & Calcareous gyttja & $9340 \pm 100$ \\
\hline 6194 & GTOII/89/4.50-4.69m & Calcareous gyttja & $13,970 \pm 190$ \\
\hline 5681 & GTOIII/89/1.05-1.25m & Wooden peat & $5660 \pm 70$ \\
\hline 6200 & GTOIII/89/1.55-1.71m & Amorphous organic matter & $10,560 \pm 180$ \\
\hline 4522 & GTOIII/89/1.84m & Amorphous organic matter & $10,930 \pm 520$ \\
\hline 6201 & GTOIII/89/1.94-2.05n & Peat & $11,510 \pm 150$ \\
\hline 4521 & GTOIV/89/1.22-1.37m & Amorphous organic matter & $2720 \pm 100$ \\
\hline 4542 & GTOIV/89/1.44-1.55m & Amorphous organic matter & $3550 \pm 110$ \\
\hline 5703 & GTOIV/89/2.77-2.90m & Calcareous gyttja & $5890 \pm 60$ \\
\hline 6202 & GTOIV/89/2.94-3.15m & Calcareous gyttja & $6200 \pm 130$ \\
\hline 6203 & GTOIV/89/3.60-3.70m & Calcareous gyttja & $10,750 \pm 150$ \\
\hline 6205 & GTOV/89/1.42-1.52m & Peat & $2150 \pm 100$ \\
\hline 6209 & GTOV/89/2.18-2.35m & Calcareous gyttja & $4110 \pm 110$ \\
\hline 6221 & GTOV/89/2.48-2.60m & Organic detritus & $2970 \pm 100$ \\
\hline 4564 & GTOV/89/2.48-2.60m & Charcoal & $2480 \pm 150$ \\
\hline 4557 & GTOV/89/3.00-3.12m & Detrital gyttja & $5440 \pm 120$ \\
\hline 6210 & GTOV/89/3.32-3.42m & Calcareous gyttja & $8200 \pm 150$ \\
\hline 4565 & GTOV/89/4.60-4.70m & Amorphous organic matter & $10,280 \pm 300$ \\
\hline 4558 & GTOV/89/5.30-5.45m & Sand with organic matter & $13,400 \pm 260$ \\
\hline 6215 & GTOV/89/5.57-5.77m & Calcareous gyttja & $12,480 \pm 170$ \\
\hline 6212 & GTOVI/89/1.0-1.1m & Moss peat & $5300 \pm 130$ \\
\hline 6214 & GTOVI/89/2.0-2.1m & Moss peat & $9910 \pm 140$ \\
\hline 6217 & GTOVI/89/2.2-2.3m & Amorphous organic matter & $11,230 \pm 150$ \\
\hline 5696 & GTO301/89/6.0-6.3m & Calcareous gyttja & $13,140 \pm 170$ \\
\hline 6220 & GTO301/89/6.30-6.35m & Amorphous organic matter & $11,840 \pm 160$ \\
\hline 5789 & GTO303/89/4.5-4.7m & Gyttja with organic detritus & $11,700 \pm 130$ \\
\hline 6297 & GTO303/89/5.3-5.4m & Calcareous gyttja & $12,280 \pm 200$ \\
\hline 5778 & GTO303/89/5.6-5.8m & Calcareous gyttja & $12,660 \pm 130$ \\
\hline 6753 & $\mathrm{G} 1 / 92 / 4.0-4.1 \mathrm{~m}$ & Peat & $8160 \pm 120$ \\
\hline 6764 & $\mathrm{G} 1 / 92 / 4.27-4.33 \mathrm{~m}$ & Peat & $11,250 \pm 120$ \\
\hline 6754 & $\mathrm{G} 2 / 92 / 1.50-1.59 \mathrm{~m}$ & Peat & $7090 \pm 120$ \\
\hline 6759 & $\mathrm{G} 2 / 92 / 4.12-4.31 \mathrm{~m}$ & Peat & $12,750 \pm 150$ \\
\hline 7227 & $\mathrm{G} 3 / 92 / 2.34-2.38 \mathrm{~m}$ & Peat & $8680 \pm 70$ \\
\hline 6783 & $\mathrm{G} 3 / 92 / 4.53-4.60 \mathrm{~m}$ & Peat & $13,020 \pm 160$ \\
\hline
\end{tabular}


TABLE 4. (Continued)

\begin{tabular}{cllr}
\hline $\begin{array}{c}\text { Lab no. } \\
\text { (Gd-) }\end{array}$ & Sample, depth & Sample material & ${ }^{14}$ C age (BP) \\
\hline 4932 & G5/92/2.83-3.0m & Peat & $7220 \pm 150$ \\
4933 & G5/92/3.98-4.02 & Calcareous gyttja & $8540 \pm 100$ \\
4934 & G5/92/6.45-6.55m & Calcareous gyttja & $8820 \pm 180$ \\
6762 & G5/92/8.1-8.13m & Calcareous gyttja & $11,680 \pm 140$ \\
4924 & G5/92/8.7-8.8m & Calcareous gyttja & $12,500 \pm 450$ \\
4936 & G20/92/4.80-4.85 & Peat & $13,240 \pm 150$ \\
4935 & G22/92/2.0-2.12m & Peat & $4020 \pm 70$ \\
4937 & G33/92/1.8-1.9m & Peat & $7700 \pm 120$ \\
7187 & GM43/92/0.65-0.67 & Tufa & $7730 \pm 60$ \\
7258 & G56/92 & Lignite & $>43,000$ \\
7364 & G1/93WD/7.6m & Lignite & $34,300 \pm 700$ \\
7363 & G2/93/0.60-0.80m & Soil & $1480 \pm 50$ \\
7353 & G2/93/0.98-1.02m & Calcareous gyttja & $12,120 \pm 70$ \\
7352 & G2/93/1.50-1.55m/C & Calcareous gyttja & $12,720 \pm 100$ \\
6900 & G2/93/1.50-1.55m/O & Calcareous gyttja & $8970 \pm 130$ \\
8053 & E5/92/0.65-0.75m & Fossil soil & $3650 \pm 170$ \\
8054 & A1/92/2.95-3.0m & Organic silt & $8100 \pm 200$ \\
8054 & G3/92/1.9-1.96m & Sand with organic layers & $4400 \pm 160$ \\
8055 & J3/92/0.4-0.45m & Peat & $2330 \pm 180$ \\
\hline
\end{tabular}

\section{Cores GTO/89}

In all GTO cores, except GTO301/89 and GTO303/89, lacustrine marls of different thickness topped by peat overlie a basal sand layer. In cores GTOII/89, GTOIV/89 and GTOV/89, which show direct hydrological relations with the Gościąż Lake basin, layers of decayed organic sediments and sandy humus separate a series of lacustrine sediments that formed when the water table in the lake was $c a$. $2.5 \mathrm{~m}$ lower than at present. This may be regarded as an indicator of an exceptionally dry period.

The scatter of ${ }^{14} \mathrm{C}$ dates obtained on lacustrine gyttja, observed in the bottom of profile GTOI/89 (Fig. 4), does not significantly exceed the limits predicted from comparative analysis of ${ }^{14} \mathrm{C}$ dates obtained on bulk samples of laminated sediment and the corresponding varve dates or AMS dates of macrofossils. Four dates on the organic fractions of lake marl samples at depths ranging from $7.8 \mathrm{~m}$ to $7.93 \mathrm{~m}$ yield a mean value of $13,440 \pm 250 \mathrm{BP}$. Given a reservoir correction of $2000 \pm 120 \mathrm{yr}$, the beginning of lacustrine sedimentation in profile GTOI/89 may be dated to several centuries before $11,440 \pm 300 \mathrm{BP}$.

Markedly similar sequences can be observed in profiles GTOIV/89 and GTOV/89, from the Mielec Lake shore (4 and 5 in Fig. 3). Decayed organic matter directly overlies lacustrine gyttja in profile GTOIV/89, indicating a break in sedimentation and the beginning of a dry episode and low water level. ${ }^{14} \mathrm{C}$ dates on the organic fractions of the basal and top layers of the lacustrine series are 10,750 $\pm 150 \mathrm{BP}$ (obtained on gyttja) and $5890 \pm 60 \mathrm{BP}$, respectively. In profile GTOV/89, lacustrine gyttja accumulation is delimited by two ${ }^{14} \mathrm{C}$ dates, $8200 \pm 150 \mathrm{BP}$, obtained on amorphous organic matter, and $5440 \pm 120 \mathrm{BP}$, obtained on mursh, from under- and overlying lacustrine series, respectively. Because the two profiles were taken from proximate sites in similar geomorphological settings, we assume that deposition of amorphous organic matter and mursh in both profiles was approximately synchronous. If so, the beginning of lacustrine accumulation in profile GTOIV may be dated to 8750 $\mathrm{BP}$, after applying the reservoir correction of $2000 \mathrm{yr}$. 


\section{Cores G/92}

We sampled cores from sites 17-20 (Fig. 3) from low peat bogs during several seasons of field work. According to geomorphological and geological data, these cores should reflect hydrological changes in the lake basin. We selected ${ }^{14} \mathrm{C}$-dated samples from these cores to supplement the determinations made earlier on cores GTO/89, which had few peaty organic horizons. Figure 5 shows the stratigraphy of the sediments; Table 4 lists the ${ }^{14} \mathrm{C}$ results.

\section{Lake Terraces}

We collected four samples from lake terraces identified in the morphology of the southeastern lake shore (sites 17-20 in Fig. 3). Sample LT-J3/92 was taken from a peat layer in the spring terrace (site 18 in Fig. 3). Other samples were dispersed organic dust from lake sands of the beach facies.

\section{RADIOCARBON CHRONOLOGY OF SEDIMENTS IN NEIGHBORING LAKES}

We dated cores from three other lakes forming the Na Jazach lake complex and from Mrokowo and Swięte Lakes (Fig. 1; Table 5). This system of lakes and peaty depressions has no common drainage; Ruda Creek drains the eastern area and the Zuzanka River drains the western area. Mrokowo and Święte Lakes are not drained.

TABLE 5. ${ }^{14} \mathrm{C}$ Dates From Cores Taken in the Na Jazach Lake System

\begin{tabular}{cllc}
\hline $\begin{array}{c}\text { Lab no. } \\
\text { (Gd-) }\end{array}$ & Sample, depth & Sample material & ${ }^{14} \mathrm{C}$ age (BP) \\
\hline 6369 & Wirzchoń/86/12.4-12.5m & Peat (?) & $13,770 \pm 150$ \\
4763 & Brzózka/91/6.75-6.84m & Algal gyttja & $4510 \pm 80$ \\
6589 & Brzózka/91/11.35-11.45m & Calcareous gyttja & $11,340 \pm 150$ \\
4679 & Mielec 3/90/13.90-13.95m & Calcareous gyttja & $14,380 \pm 270$ \\
6370 & Mielec 3/90/13.95-14.0m & Calcareous gyttja & $12,590 \pm 190$ \\
4692 & Mielec 3/90/15m & Peat & $13,280 \pm 320$ \\
6491 & Swięte/91/4.0-4.1m & Algal gyttja & $2840 \pm 100$ \\
6485 & Święte/91/8.05-8.14m & Algal gyttja & $4510 \pm 110$ \\
5948 & Siwete/91/9.65-9.75m & Calcareous gyttja & $7010 \pm 90$ \\
6487 & Swiette/91/11.86-11.88m & Bark fragments & $10,060 \pm 140$ \\
6467 & Swiette/91/12.22-12.27m & Peat & $12,410 \pm 170$ \\
6553 & Swięte/91/13.16-13.18m & Organic detritus & $11,030 \pm 170$ \\
6684 & Mrokowo/91/7.9-8.0m & Gyttja & $7760 \pm 110$ \\
6685 & Mrokowo/91/11.9-12.0m & Gyttja & $8530 \pm 110$ \\
6720 & Mrokowo/91/12.9-13.0m & Rotten peat & $9480 \pm 120$ \\
6721 & Mrokowo/91/14.0-14.1m & Peat & $12,030 \pm 130$ \\
\hline
\end{tabular}

Wirzchoń Lake was cored in 1986; other cores were taken in 1990 and 1991. Figure 6 shows the stratigraphy of all the cores used in this study. The sediments of the Wirzchon and Mielec Lakes begin with a thin peat layer at the base, overlain by an almost uniform series of calcareous gyttjas. The profile obtained from Brzózka Lake is more differentiated, showing distinct irregular lamination at its base (between $c a .6 .5$ and $11.5 \mathrm{~m}$ ); the core taken from this lake probably did not reach the bottom of the sediment. For dating, we used the basal segment of the core, consisting of algal gyttja with sand admixture.

Sediments from two lakes west of the Na Jazach lake complex begin with a layer of mursh (Mrokowo/91) or sandy peat (Swięte/91) (Fig. 6). In the latter profile, sand with some macrofossils 


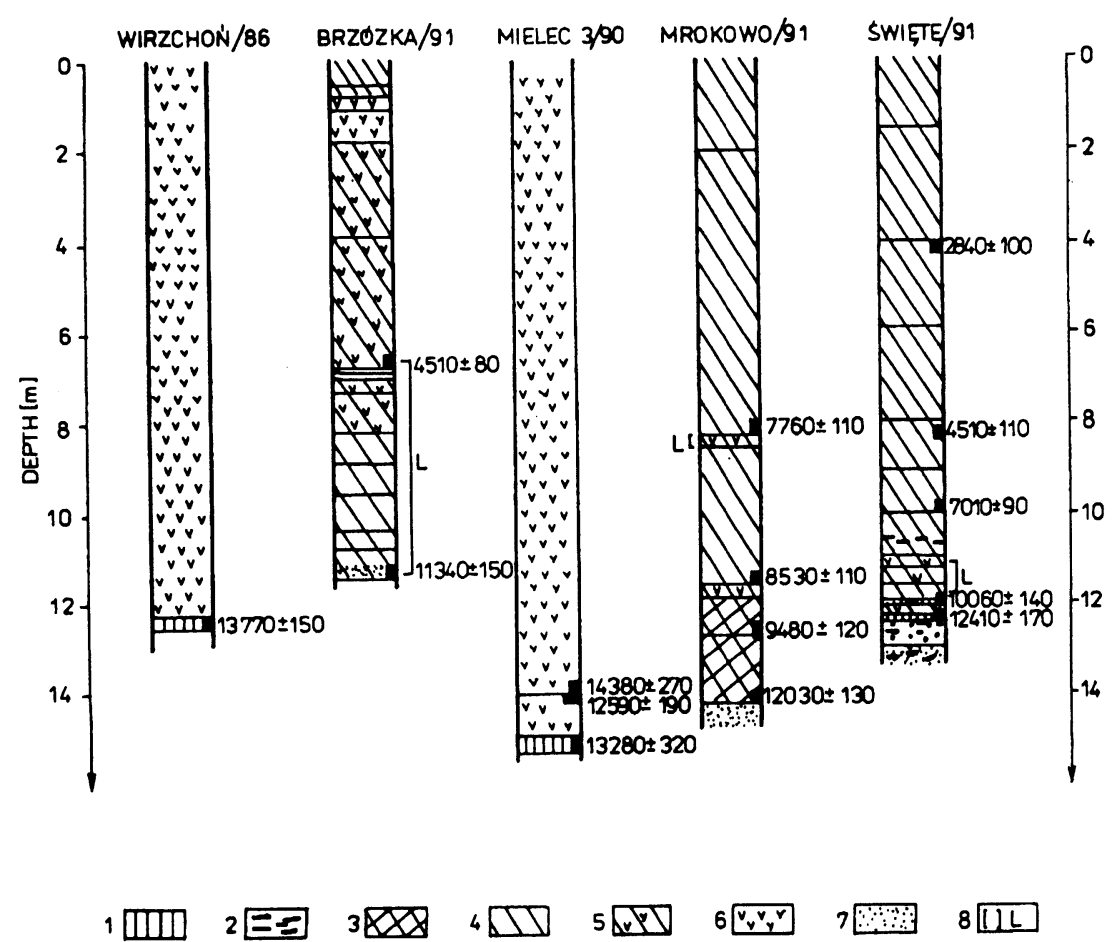

Fig. 6. Cores taken from other lakes in the study area. Coring location are • in Fig. 1A. Key: 1. peat; 2. macroscopic plant remains; 3 . decayed organic matter; 4. algal gyttja; 5. algal-calcareous gyttja; 6. calcareous gyttja; 7. sand; 8. core segments with laminated sediment. Horizontal lines mark minor lithological boundaries.

overlies the organic level. Although both profiles consist mainly of non-calcareous algal gyttja, we found relatively thin layers of laminated algal-calcareous gyttja in each (Fig. 6). ${ }^{14} \mathrm{C}$ dates obtained on basal peat layers from Wirzchon and Mielec Lakes, respectively 13,770 \pm 150 and 13,280 \pm 320 $\mathrm{BP}$, indicate very early lacustrine sedimentation. These dates correlate well with the results obtained on basal peaty layers in Gościąż Lake $(13,300 \pm 200 \mathrm{BP}$, core PTG/91, and 13,150 $\pm 110 \mathrm{BP}$, the mean of four dates on basal peat from core G4/90). Dates obtained on basal organic levels in profiles from Mrokowo and Swięte Lakes (Fig. 6) indicate that the lacustrine sedimentation began almost synchronously in both lakes, but $c a$. 1 ka later than in the Na Jazach lake complex.

\section{WATER-LEVEL CHANGES}

Detailed and accurate reconstruction of water-level changes in Gościąż Lake from ${ }^{14} \mathrm{C}$-dated facial and lithological changes observed in sediment cores taken from its shore and environs is complex. Differentiation of sediments is controlled by both local geomorphology in the beach zone and by short-term water-level changes resulting from seasonal variation in precipitation. Despite these limitations, one can distinguish periods of high water level related to accumulating lacustrine gyttja. One may assume that lacustrine gyttja accumulation records high water levels in more than one profile. On the other hand, low water levels are recorded by layers of organic sediments such as peat and amorphous organic matter. Layers of mursh or decayed organic matter indicate arid periods with very low lake levels. 
Cores GTO/89 and G/92 provide records of three periods of lacustrine gyttja accumulation, indicating high water levels. The oldest period lasted from $c a .11 .8$ to $10.2 \mathrm{ka} \mathrm{BP}$, and the youngest from 2.5 to $2.1 \mathrm{ka}$ BP. The duration of the middle period, which is not well documented in Figure 7, may be estimated at 8.2 to $7.0 \mathrm{ka}$ BP. Almost all GTO/89 profiles (GTO I, II, III, V and 301) record the older episode of high water. Determining the beginning of calcareous gyttja accumulation in profiles GTO II, IV and V is problematic because corresponding dates are based on organic fractions of lacustrine sediment and may be subject to inaccuracy in the applied reservoir correction. Assuming a correction of $2000 \mathrm{yr}$, calcareous gyttja accumulation in profiles GTOI/89 and GTOII/89 begins ca. $12 \mathrm{ka}$ BP. If this is the case, gyttja accumulation begins synchronously in profiles GTO I, II, III and 301 in the interval between 11.8 and $10.2 \mathrm{ka}$ BP. The short episode of lacustrine accumulation, marked by a thin gyttja layer in profile GTO V (dated to $12,480 \pm 170 \mathrm{BP}$ ), coincides, after reservoir correction, with the end of that period. Relatively precise timing of younger episodes of lacustrine sedimentation is possible from ${ }^{14} \mathrm{C}$ dates obtained on peat, mursh or amorphous organic matter. ${ }^{14} \mathrm{C}$ dates determining the beginning and end of lacustrine sedimentation obtained from peat layers in profiles G/92 correlate quite well with dates obtained on lithological boundaries of profiles $\mathrm{GTO} / 89$.

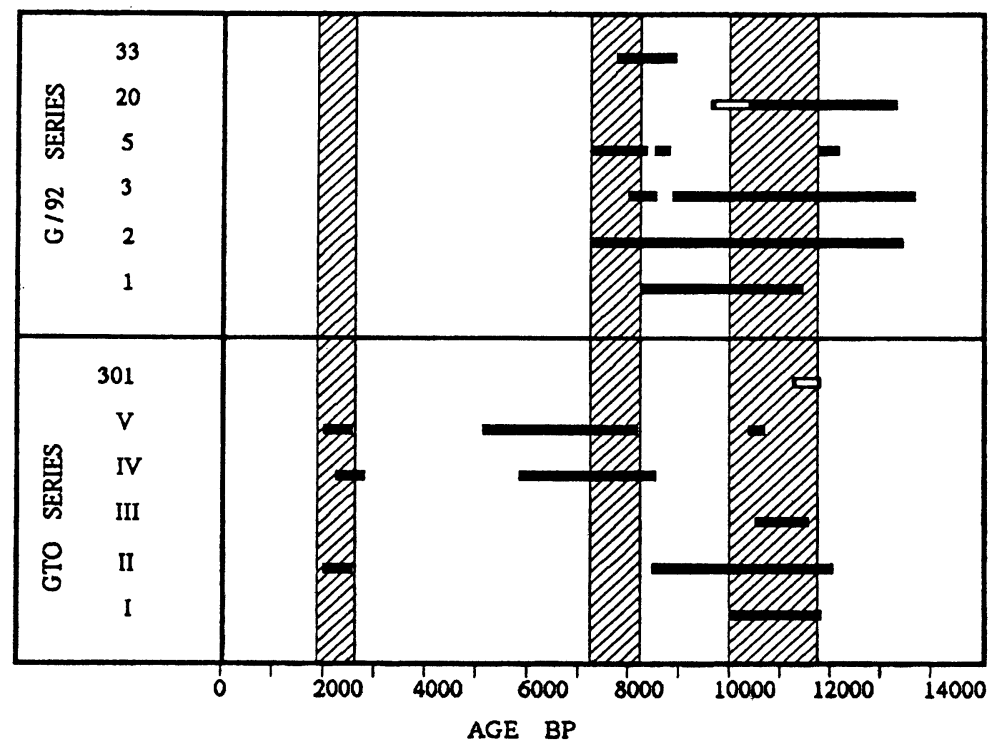

Fig. 7. Periods of lacustrine gyttja sedimentation near Gosciąż Lake

We recorded no lacustrine sediments between 5.4 and $2.7 \mathrm{ka}$ BP, which may indicate an extremely low lake level during this period. With the water level in Gościaz Lake at $62 \mathrm{~m}$ asl, Tobylka Bay was probably a shallow boggy basin. Figure 8 shows a reconstruction of water-level changes in Gościąż Lake from ${ }^{14} \mathrm{C}$-dated lithological boundaries of sediments around the lake, based on the above-mentioned assumptions.

We distinguished a rapid rise in the Gościąż Lake level ca. $11.8 \mathrm{ka}$ BP by observing a disturbance at the eastern lake shore associated with a landslide on the sandy bank. A thick series of fine-grained sands overlying lacustrine sediment in profile GTO301/89 records this event. Perhaps the sandy layer at the bottom of profile G1/87 was deposited at the same time (Wicik and Więckowski 1991). Similar trends in water-level changes between 8100 and 2300 BP may be deduced from ${ }^{14} \mathrm{C}$ dating 


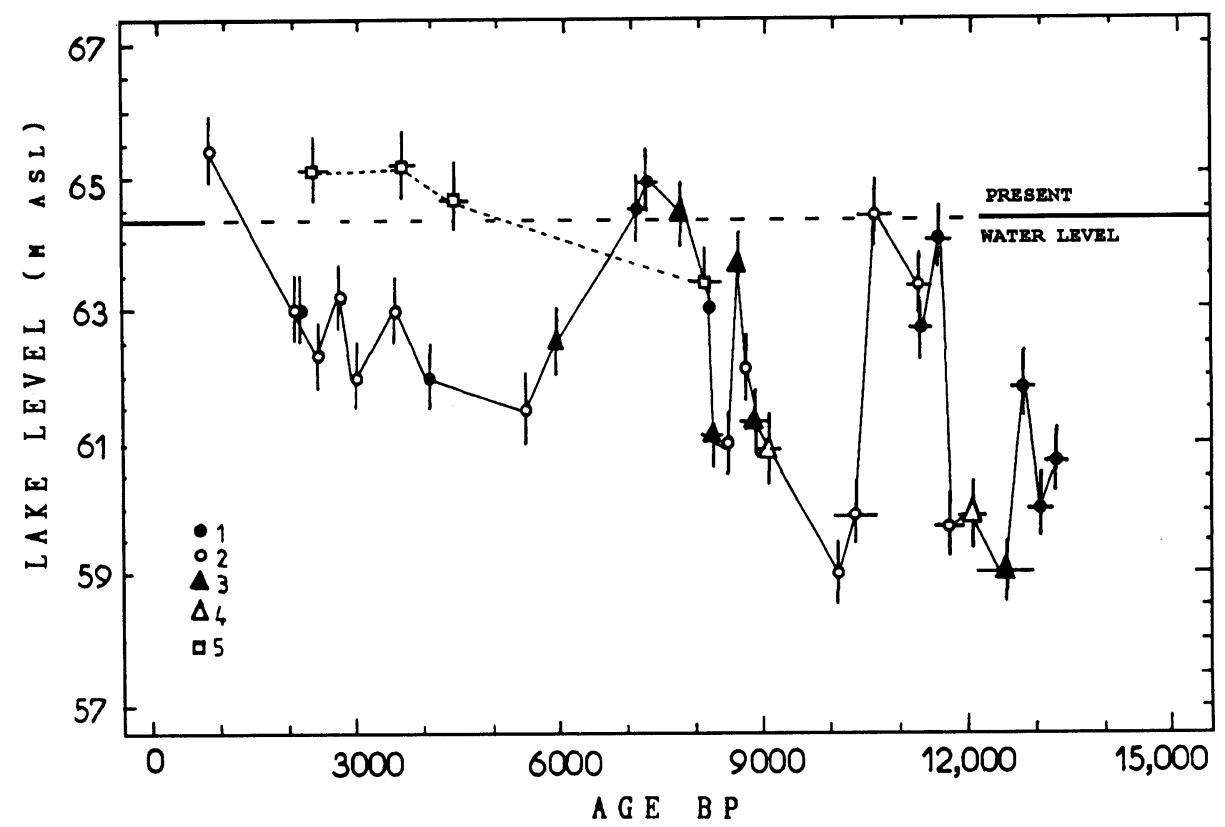

Fig. 8. Changes of water levels in Gosciąż Lake from the Late Glacial to the present, expressed as changes in the elevation of the water table ( $\mathrm{m}$ asl) estimated from lithological studies and ${ }^{14} \mathrm{C}$-dating of cores around the lake. Key: 1. peat; 2 . mursh; 3 . detrital gyttja; 4 . lake marl $\left(T_{R}=2 \mathrm{ka}\right) ; 5$. lake terraces.

of lake terraces. A water-level rise of $c a .1 .5 \mathrm{~m}$ during this period corresponds to the formation of a terrace dated $c a .2300 \mathrm{BP}$ at altitude $c a .1 .5 \mathrm{~m}$ higher than that of the terrace at $8100 \mathrm{BP}$.

\section{CONCLUSIONS}

Lithological boundaries between lacustrine gyttja and non-lacustrine sediments reflect changes in the water level in Gościąż Lake. Correlating these locations with the ${ }^{14} \mathrm{C}$ dates enables us to reconstruct fluctuations in the lake's water table during the last $13 \mathrm{ka}$ BP. Thus, the highest and lowest water levels of Gościąż Lake (Fig. 8) should correspond to other records of temperate-zone lakelevel changes during the Late Glacial and Holocene. Holocene lake-level fluctuations recorded in southern Sweden by Digerfeldt (1988:173, Fig. 11) indicate the first distinct, rapid lake-level decline at 9.7-9.5 ka BP, and the second long period of a low lake level between 6.5 and $3.5 \mathrm{ka}$ BP. Further, each of the nine lakes studied shows low levels between 2.7 and $2.0 \mathrm{ka} \mathrm{BP}$. We have almost exactly replicated these findings with our data (Figs. 7 and 8 ).

The record of Holocene lake-level fluctuations in Jurassian and French subalpine lakes, obtained by Magny $(1992,1993)$ shows distinct similarities to the Gościąz Lake record. The two oldest transitions from transgression to regression, noted at 9.5-8.0 ka and 7.5-6.0 ka BP in French lakes, are also visible in the trend of Gościąż lake-level changes. No such distinct similarities occur in the late Holocene, but both records agree fairly well.

Gościąż lake-level changes also correlate to regional patterns of high and low lake levels obtained from statistical analyses of lakes in eastern North America (Harrison 1989) and Europe (Harrison, Prentice and Guiot 1993). Thus, we conclude that the behavior of Gościąz Lake during the last 12 
ka fairly accurately reflects global climate changes in the temperate zone during the Late Glacial and Holocene.

\section{ACKNOWLEDGMENTS}

This study was initiated by the Committee of Quaternary Research of the Polish Academy of Sciences. The present report is part of research project PB 740/6/91, sponsored by the State Committee for Scientific Research.

\section{REFERENCES}

Arnold, M., Bard, E., Maurice, P. and Duplessy, J.-C. 1987 C-14 dating with Gif-sur-Yvette tandetron accelerator: Status report. In Gove, H. E., Litherland, A. E. and Elmore, D., eds., Proceedings of the 4th International Conference on Accelerator Mass Spectrometry. Nuclear Instruments and Methods in Physics Research B29: 120-123.

Digerfeldt, G. 1988 Reconstruction and regional correlation of Holocene lake-level fluctuations in Lake Bysjön, South Sweden. Boreas 17:165-172.

Goslar, T. 1993 Varve chronology of laminated sediments of Lake Gościąż. Polish Botanical Studies, Guidebook Series 8: 105-119 (in Polish).

Goslar, T., Kuc, T., Pazdur, M. F., Ralska-Jasiewiczowa, M., Różański, K., Szeroczyńska, K., Walanus, A., Wicik, B., Więckowski, K., Arnold, M. and Bard, E. 1992 Possibilities for reconstructing radiocarbon level changes during the late glacial by using a laminated sequence of Gościąż Lake. In Long, A. and Kra, R. S., eds., Proceedings of the 14 th International ${ }^{14} \mathrm{C}$ Conference. Radiocarbon 34(3): 826-832.

Goslar, T., Kuc, T., Ralska-Jasiewiczowa, M., Różański, K., Arnold, M., Bard, E., van Gel, B., Pazdur, M. F., Szeroczyńska, K., Wicik, B., Więckowski, K. and Walanus, A. 1993 High-resolution lacustrine record of the Late Glacial/Holocene transition in Central Europe. Quaternary Science Reviews 12: 287-294.

Goslar, T., Pazdur, A., Pazdur, M. F. and Walanus, A. 1989 Radiocarbon and varve chronologies of annually laminated lake sediments of Gościaż Lake, Central Poland. In Srdox, D., Long, A. and Kra, R. S., eds., Proceedings of the 13 th International ${ }^{14} \mathrm{C}$ Conference. Radiocarbon 31(3): 940-947.

Harrison, S. P. 1989 Lake levels and climatic changes in eastern North America. Climate Dynamics 3: 157-167.

Harrison, S. P., Prentice, C. and Guiot, J. 1993 Climatic controls on Holocene lake-level changes in Europe. Climate Dynamics 8: 189-200.

Madeyska, T. 1993 Geomorphological map of the Plock Basin. Polish Botanical Studies, Guidebook Series 8: 9-13 (in Polish).

Magny, M. 1992 Holocene lake-level fluctuations in the Jura and the northern subalpine ranges, France: Regional patterns and climatic implications. Boreas 21: 319-334.
1993 Solar influences on Holocene climatic changes illustrated by correlations between past lake-level fluctuations and atmospheric ${ }^{14} \mathrm{C}$ record. Quaternary $R e$ search 40: 1-9.

Pazdur, A., Fontugne, M. R., Goslar, T. and Pazdur, M. F. (ms.) Late Glacial and Holocene water-level changes of Gościaż Lake, Central Poland, derived from carbon isotope studies of laminated sediment. Submitted to Quaternary Science Reviews.

Pazdur, A., Pazdur, M. F., Wicik, B. and Więckowski, K. 1987a Radiocarbon chronology of annually laminated sediments from the Gościąz Lake. Bulletin of the Polish Academy of Sciences, Earth Sciences 35: 139-145.

Pazdur, A. and Starkel, L. 1989 New approach to explanation of changes in the volume and water level of the Gościąż Lake. Zeszyty Naukowe Politechniki Slaskiej, Seria Matematyka-Fizyka 57. Geochronometria 5: 29-44.

Pazdur, M. F., Awsiuk, R., Goslar, T., Pazdur, A., Walanus, A., Wicik, B. and Więckowski, K. 1987b. Calibrated radiocarbon chronology of annually laminated sediments from the Gościąz Lake. Zeszyty Naukowe Politechniki Slaskiej, Seria Matematyka-Fizyka 56. Geochronometria 4: 69-83.

Ralska-Jasiewiczowa, M., Wicik, B. and Więckowski, K. 1987 Lake Gosciąż—a site of annually laminated sediments covering 12,000 years. Bulletin of the Polish Academy of Sciences, Earth Sciences 35: 139-145.

Różański, K., Goslar, T., Dulinski, M., Kuc, T., Pazdur, M. F. and Walanus, A. 1992 The Late Glacial-Holocene transition in laminated sediments of the Lake Gosciąz (Central Poland). In Bard, E. and Broecker, W. S., eds., The Last Deglaciation: Absolute and Radiocarbon Chronologies. NATO ASI Series I, Global Environmental Change, Vol. 2. Berlin/Heidelberg, Springer-Verlag: 69-80.

Sierzega, P. and Narwojsz, A. (ms.) 1988 The grip of groundwater from Quaternary sediment in the Jozefowek region near Wlocawek. Archive of Geological Enterprise, Gdansk Division, Gdansk (in Polish).

Skompski, S. 1971 Comments on the Detailed Geological Map of Poland, Scale 1:50000, Dobrzyn Chart. Wydawnictwa Geologiczne, Warsaw (in Polish).

Stuiver, M. and Polach, H. A. 1977 Discussion: Reporting of ${ }^{14} \mathrm{C}$ data. Radiocarbon 19(3): 355-363. 
Wicik, B. and Więckowski, K. 1991 The sediments of the "Na Jazach" lakes in the Plock Basin-conditions of their sedimentation and role in reconstruction and prognosis of the natural environment. Przeglad Geograficzny 63: 57-76 (in Polish).
Więckowski, K. 1993 The current state of recognition of bottom sediments in the "Na Jazach" lakes according to their macroscopic features. Polish Botanical Studies, Guidebook Series 8: 77-92 (in Polish). 